\title{
Investigation of the antibiotic resistance and biofilm-forming ability of Staphylococcus aureus from subclinical bovine mastitis cases
}

\author{
Özkan Aslantaş ${ }^{* 1}$ and Cemil Demirt \\ *Department of Microbiology, Faculty of Veterinary Medicine, Mustafa Kemal University, 31030 Hatay, Turkey \\ †Vocational School of Health Services, Department of the Medical Documentation and Secretarial, Mardin Artuklu University, \\ 47500 Mardin, Turkey
}

\section{ABSTRACT}

A total of 112 Staphylococcus aureus isolates obtained from subclinical bovine mastitis cases were examined for antibiotic susceptibility and biofilm-forming ability as well as genes responsible for antibiotic resistance, biofilm-forming ability, and adhesin. Antimicrobial susceptibility of the isolates were determined by disk diffusion method. Biofilm forming ability of the isolates were investigated by Congo red agar method, standard tube method, and microplate method. The genes responsible for antibiotic resistance, biofilm-forming ability, and adhesion were examined by PCR. Five isolates (4.5\%) were identified as methicillin-resistant Staph. aureus by antibiotic susceptibility testing and confirmed by mecA detection. The resistance rates to penicillin, ampicillin, tetracycline, erythromycin, trimethoprim-sulfamethoxazole, enrofloxacin, and amoxicillin-clavulanic acid were $45.5,39.3,33,26.8,5.4,0.9$, and $0.9 \%$, respectively. All isolates were susceptible against vancomycin and gentamicin. The blaZ (100\%), tetK $(67.6 \%)$, and ermA $(70 \%)$ genes were the most common antibioticresistance genes. Using Congo red agar, microplate, and standard tube methods, 70.5, 67, and $62.5 \%$ of the isolates were found to be biofilm producers, respectively. The percentage rate of $i c a A$, icaD, and bap genes in Staph. aureus isolates were 86.6, 86.6, and $13.4 \%$, respectively. The adhesion molecules fnbA, can, and clf $A$ were detected in 87 (77.7\%), 98 (87.5\%), and 75 $(70 \%)$ isolates, respectively. The results indicated that Staph. aureus from sublinical bovine mastitis cases were mainly resistant to $\beta$-lactams and, to a lesser extent, to tetracycline and erythromycin. Also, biofilm- and adhesion-related genes, which are increasingly accepted as an important virulence factor in the pathogenesis of Staph. aureus infections, were detected at a high rate.

Received April 13, 2016

Accepted July 22, 2016.

${ }^{1}$ Corresponding author: ozkanaslantas@yahoo.com
Key words: antibiotic resistance, biofilm production, mastitis, Staphylococcus aureus

\section{INTRODUCTION}

Mastitis is a worldwide problem causing enormous economic losses in dairy industry due to poor milk quality, reduced milk yield, increased usage of drugs and veterinary service, as well as high culling rate of affected cattle and sometimes death due to the disease (Kumar et al., 2010). Staphylococcus aureus is one of the leading agents isolated from bovine mastitis cases and is characterized by lower cure rates compared with other mastitis pathogens. This phenomenon is mainly explained by acquisition of antimicrobial resistance and their biofilm-forming ability (Taponen and Pyörälä, 2009).

Misuse and widespread use of antibiotics for the treatment and prevention of bovine mastitis leads to development and emergence of resistance among mastitis pathogens against antibiotics (Oliver and Murinda, 2012). Beta-lactams have been widely used to treat mastitis cases for several decades, but their efficiency is reduced due to $\beta$-lactamase synthesis, which is encoded by blaZ (Olsen et al., 2006). Another $\beta$-lactam resistance mechanism, called methicillin/oxacillin resistance, is mediated by low-affinity penicillin-binding protein (PBP2a) encoded by mecA (Sawant et al., 2009).

Another mechanism significantly affecting the effectiveness of treatment of mastitis cases is the production of biofilm. Biofilm formation reduces susceptibility of Staph. aureus to various antibiotics by decreasing diffusion of antibiotics inside biofilm matrix and becoming resistant to high concentrations of antimicrobials. Biofilm also helps (1) bacteria adhesion and colonization of mammary gland tissue, (2) evasion from harsh conditions within host and phagocytosis, and (3) persistence of infection. The $i c a A$ and $i c a D$ genes, found at the ica locus present in Staph. aureus and Stahpylococcus epidermidis, play a significant role in biofilm formation. Whereas icaA encodes $\mathrm{N}$-acetylglucosaminyltransfer- 
ase, responsible for the $N$-acetylglucosamine oligomers from UDP- $N$-acetylglucosamine (Arciola et al., 2001), $i c a D$ plays a critical role in the maximal expression of $\mathrm{N}$-acetylglucosaminyltransferase, leading to the phenotypic expression of the capsular polysaccharide (Gerke et al., 1998). In addition to the above mentioned genes, a surface protein called biofilm-associated protein ( $b a p)$ has been reported to be involved in biofilm formation of bovine Staph. aureus strains. The bap gene implicates biofilm formation by promoting primary attachment and adhesion to inert and live surfaces (Cucarella et al., 2004).

Staphylococcus aureus have a variety of adhesins playing an important role in the onset of infection by binding host tissues and accepted as an important virulence factors. These adhesins specifically interact adhesive matrix components found on host tissue and designated as the microbial surface component recognizing adhesive matrix molecules (MSCRAMM; Patti et al., 1994). Of these MSCRAMM, fibronectin-binding protein A $(f n b A)$, clumping factor A (clf A), and collagen-binding protein (cna) are accepted as important virulence factors in binding to host cell, colonization and invasion (Haveri et al., 2008).

The aims of the current study were (1) to investigate the antibiotic susceptibility and antibiotic resistance genes, (2) determine the ability of biofilm synthesis and the genes responsible for slime synthesis of the isolates, and (3) search for cna, fnbA, and clfA genes coding MSCRAMM in Staph. aureus strains from subclinical mastitis.

\section{MATERIALS AND METHODS}

\section{Bacterial Isolates}

A total of 112 Staph. aureus strains isolated from milk samples submitted to the Department of Microbiology laboratory (Mustafa Kemal University) from 2008 to 2010 were studied. The strains were isolated from 330 dairy cattle belonging to 26 family-sized farms (average of 15-20 cattle) located in southern Turkey. Subclinical bovine mastitis cases were detected using California mastitis test. Milk samples were inoculated onto blood agar supplemented with $5 \%$ defibrinated sheep blood. The isolates were identified according to classical microbiological methods (Quinn et al., 1998).

\section{Antimicrobial Susceptibility Testing}

Antimicrobial susceptibility of the isolates were determined using disk diffusion method according to the guidelines of Clinical Laboratory Standards Institute
(2008). The antimicrobials used were penicillin $(10 \mu \mathrm{g})$, ampicillin $(10 \mu \mathrm{g})$, amoxicillin-clavulanic acid (20/10 $\mu \mathrm{g})$, oxacillin $(1 \mu \mathrm{g})$, vancomycin $(30 \mu \mathrm{g})$, gentamycin $(10 \mu \mathrm{g})$, enrofloxacin $(5 \mu \mathrm{g})$, erythromycin $(15 \mu \mathrm{g})$, tetracycline $(30 \mu \mathrm{g})$, and trimethoprim-sulfamethoxazole $(1.25 / 23.75 \mu \mathrm{g})$. Staphylococcus aureus (ATCC 29213) was used as a quality-control strain.

\section{Biofilm Formation}

Biofilm-forming ability of Staph. aureus strains were determined using 3 different methods.

\section{Congo Red Agar Method}

Qualitative detection of biofilm production by Staph. aureus strains were determined using Congo Red Agar (CRA) plates as previously described by Freeman et al. (1989). Strains producing black and rough colonies were considered biofilm producers.

\section{Standard Tube Method}

The qualitative assay for biofilm formation was performed according to the method described by Christensen et al. (1985). Presence of adherent film stained with safranine on the inner surface of the standard tubes (ST) was accepted as indication of positive result. The biofilms formed were scored as negative $(-)$, weak $(+)$, moderate $(++)$, and strong $(+++)$.

\section{Microplate Method}

Quantitative biofilm determination was carried out using the microplate (MP) method described by Christensen et al. (1985) in tissue culture plates with 96 flat-bottomed well. All the experiments were repeated at least twice, and the values of optical density were then averaged. A 3-grade scale was used to evaluate the biofilm-forming ability of strains: optical density $<0.120(-)$; optical density $=0.120-0.240(+)$; and optical density $>0.240(++)$.

\section{DNA Isolation and PCR Amplification of Antibiotic Resistance and Biofilm Genes}

Bacterial DNA extraction was performed using commercial DNA extraction kit (InstaGene Matrix, BioRad, Hercules, CA). The PCR amplification of intracellular adhesion genes (icaA and $i c a D)$, bap gene, and adhesion molecules (cna, clfA, fnbA) were determined as previously described by Vasudevan et al. (2003), Cucarella et al. (2004), and Arciola et al. (2005). Antimi- 
Table 1. Antimicrobial resistance phenotype and genotype of Staphylococcus aureus isolates

\begin{tabular}{|c|c|c|}
\hline Phenotype $^{1}$ & Genotype & Isolates, no. \\
\hline $\mathrm{P}, \mathrm{AMP}$ & blaZ & 17 \\
\hline $\mathrm{P}, \mathrm{AMP}, \mathrm{TE}$ & blaZ, tetK & 10 \\
\hline TE, E & tetK, ermC & 7 \\
\hline $\mathrm{P}, \mathrm{AMP}, \mathrm{TE}, \mathrm{E}$ & blaZ, tetK, ermC & 6 \\
\hline $\mathrm{P}, \mathrm{TE}, \mathrm{E}$ & blaZ, tet $M$, ermA & 2 \\
\hline $\mathrm{P}, \mathrm{E}, \mathrm{AMP}$ & blaZ, ermC & 2 \\
\hline OXA, TE & mecA, tetK & 2 \\
\hline P, TE, E, STX & blaZ, ermC, tetM & 2 \\
\hline $\mathrm{E}, \mathrm{P}$ & blaZ, ermC & 2 \\
\hline $\mathrm{TE}, \mathrm{E}$ & tetK, tet $M$, erm $C$ & 2 \\
\hline $\mathrm{P}, \mathrm{TE}, \mathrm{E}$ & blaZ, tet $M$, ermA & 1 \\
\hline $\mathrm{E}$ & ermA, ermC & 1 \\
\hline $\mathrm{P}, \mathrm{AMP}, \mathrm{TE}$ & blaZ, tet $M$ & 1 \\
\hline $\mathrm{P}, \mathrm{AMP}, \mathrm{OXA}$ & blaZ, mecA & 1 \\
\hline P, AMP, STX & blaZ & 1 \\
\hline $\mathrm{P}, \mathrm{AMP}, \mathrm{TE}, \mathrm{E}$ & blaZ, tet $M$, ermA & 1 \\
\hline P, AMP, OXA, TE, E & blaZ, tetM, mecA, ermA & 1 \\
\hline P, AMP, OXA, TE, E, ENR, STX & blaZ, mecA, tetM, ermA, ermC & 1 \\
\hline $\mathrm{P}, \mathrm{AMP}, \mathrm{E}, \mathrm{AMC}$ & blaZ, ermA & 1 \\
\hline P, AMP, E, STX & blaZ, ermA, ermC & 1 \\
\hline P, AMP, TE, STX & blaZ, tetK, tet $M$ & 1 \\
\hline Total & & 63 \\
\hline
\end{tabular}

crobial resistance genes related to methicillin $(m e c A)$, penicillin (blaZ), tetracycline (tet $M$, tet $K$, tet $L$, tet $O)$, aminoglycoside $\left[a a c\left(6^{\prime}\right)-I e-a p h\left(2^{\prime \prime}\right)-I a, \quad a n t\left(4^{\prime}\right)-l a\right.$ and $\left.\operatorname{aph}\left(3^{\prime}\right)-I I I a\right]$, and macrolide (ermA, ermB, and ermC) were investigated as previously reported by Jensen et al. (1999), Vesterholm-Nielsen et al. (1999), Strommenger et al. (2003), and Choi et al. (2003) using PCR assay.

\section{RESULTS}

\section{Antimicrobial Susceptibility Testing and Resistance Genes}

The data on the antimicrobial susceptibility of 112 Staph. aureus strains and resistance genes are given in Table 1. Five isolates (4.5\%) were found as methicillin-resistant Staph. aureus (MRSA) by antibiotic susceptibility (resistant to oxacillin) and confirmed by $m e c \mathrm{~A}$ detection. Various rates of resistance to penicillin (45.5\%), ampicillin (39.3\%), tetracycline (33\%), erythromycin $(26.8 \%)$, trimethoprim-sulfamethoxazole (5.4\%), oxacillin (4.5\%), enrofloxacin (0.9\%), and amoxicillin-clavulanic acid $(0.9 \%)$ were detected. All isolates were susceptible to vancomycin and gentamicin. All penicillin-resistant isolates contained blaZ. Of 37 tetracycline-resistant isolates, 25 possessed tetK, 9 had tet $M$, whereas 3 carried both tet $K$ and tet $M$. Among the erythromycin-resistant isolates $(\mathrm{n}=30)$, ermA was detected in 21 isolates, erm $C$ was detected in 6 isolates, erm $A$ and $e r m C$ were detected in 3 isolates. None of the isolates carried aminoglycoside-resistance genes.

\section{Biofilm Formation and Biofilm-Related Genes}

Out of 112 Staph. aureus isolates, 79 (70.5\%) isolates by CRA method, 75 (67\%) isolates by MP method, and $70(62.5 \%)$ isolates by the ST method were found as biofilm producers (Table 2). Both icaA and icaD were detected in $97(86.6 \%)$ isolates, and bap were detected in $15(13.4 \%)$ isolates. Comparison of CRA, MP, and ST methods with PCR results is given in Table 3.

\section{Adhesion Genes}

Genes cna, fnbA, clfA were detected in 98 (87.5\%), 87 (77.7\%), and $75(70 \%)$ isolates, respectively.

Table 2. Screening of 112 Staphylococcus aureus isolates for biofilm production by Congo red agar (CRA), standard tube (ST), and microplate (MP) methods

\begin{tabular}{lccc}
\hline & \multicolumn{3}{c}{ Screening method } \\
\cline { 2 - 4 } $\begin{array}{lccc}\text { Biofilm } \\
\text { formation }\end{array}$ & CRA, & MP, & ST, \\
& no. $(\%)$ & no. $(\%)$ & no. $(\%)$ \\
\hline Strong & $43(38.4)$ & $27(24.1)$ & $35(31.3)$ \\
Moderate & $36(32.1)$ & $48(42.9)$ & $22(19.6)$ \\
Weak & $0(0)$ & $0(0)$ & $13(11.6)$ \\
None & $33(29.5)$ & $37(33)$ & $42(37.5)$ \\
\hline
\end{tabular}


Table 3. Evaluation of Congo red agar (CRA), standard tube (ST), and microplate (MP) methods considering PCR as the reference method

\begin{tabular}{|c|c|c|c|c|c|c|c|}
\hline Method & $\begin{array}{c}\text { Biofilm-producing } \\
\text { strains }\end{array}$ & $\begin{array}{l}\text { Strains positive } \\
\quad \text { for } i c a A D\end{array}$ & $\begin{array}{l}\text { Strains negative } \\
\quad \text { for } i c a A D\end{array}$ & $\begin{array}{c}\text { Sensitivity } \\
\%\end{array}$ & $\begin{array}{c}\text { Specificity } \\
\%\end{array}$ & $\begin{array}{c}\text { Positive predictive } \\
\text { value, } \%\end{array}$ & $\begin{array}{c}\text { Negative predictive } \\
\text { value, } \%\end{array}$ \\
\hline$\overline{\mathrm{CRA}}$ & 79 & 73 & 6 & 75.25 & 60.0 & 92.4 & 27.27 \\
\hline $\mathrm{MP}$ & 75 & 71 & 4 & 73.19 & 73.33 & 94.66 & 29.72 \\
\hline
\end{tabular}

\section{DISCUSSION}

Many previous studies showed that Staph. aureus was the most important microorganism isolated from subclinical mastitis cases in the world (Taponen and Pyörälä, 2009). Similarly, previous studies carried out in Turkey also revealed that Staph. aureus was the most common agent with various isolation rates varying between 24.63 and 39.04\% (Gulcu and Ertas, 2004; Macun et al., 2011; Yesilmen et al., 2012).

In our study, Staph. aureus isolates showed higher rate of resistance to penicillin (45.5\%). This result is not surprising, because $\beta$-lactams are widely prescribed agents to cure bovine mastitis cases in Turkey. Previous studies conducted in Turkey revealed that prevalence of penicillin resistance were $75 \%$ in Marmara region, $62 \%$ in Central Anatolia, and $63.3 \%$ in Burdur, respectively (İkiz et al., 2013; Güler et al., 2005; Turutoğlu et al., 2006). Resistance rate to tetracycline (33\%) was higher than those from findings of İkiz et al. $(2013 ; 16.6 \%)$ and Güler et al. (2005; 27.9\%), but lower than findings $(61.2 \%)$ of Turutoğlu et al. (2006), suggesting that resistance rates for Staph. aureus, such as those for other bacteria, vary regionally and are influenced by antibiotic usage. The erythromycin-resistance rate $(26.8 \%)$ was inconsistent with previous studies conducted by Ünal and İstanbulluoğlu (2009) in Kirıkkale and Tel et al. (2012) in Şanllurfa, who reported resistance rates of 4.3 and $9.3 \%$, respectively. But, Ikiz et al. (2013) reported erythromycin resistance rate as $33.33 \%$. In previous studies, generally low or no resistance against trimethoprim-sulfamethoxazole was reported in Turkey (Güler et al., 2005; Ünal and İstanbulluoğlu, 2009; Tel et al., 2012). Similarly, low resistance (5.4\%) was found against this agent in current study. In contrast to these studies, high levels resistance were reported by Turutoğlu et al. (2006) and İkiz et al. (2013) (45.6 vs. $58.83 \%$, respectively). One of the striking results of the study was very low resistance prevalence against enrofloxacin (0.9\%) and amoxicillin-clavulanic acid $(0.9 \%)$, as these drugs are critically important for the treatment of staphylococcal infections in veterinary medicine (Beco et al., 2013).

The biofilm-forming ability of staphylococci has increasingly been accepted as an important virulence trait in addition to exotoxins and surface proteins produced by staphylococci (Vancraeynest et al., 2004). Among the methods used for determining biofilm-forming ability of Staph. aureus from bovine mastitis cases, it was observed that the highest positivity was obtained by the CRA method (Vasudevan et al., 2003; Turkyilmaz and Eskiizmirliler, 2006; Dhanawade et al., 2010). In a similar manner, in the current study, higher positivity rate was found by CRA $(70.5 \%)$ than by MP $(67 \%)$ or ST $(62.5 \%)$. A discrepancy has also been reported between the results of phenotypic and genotypic methods used for the determination of biofilm forming ability of Staph. aureus isolates. Indeed, 18 icaA- and icaD-positive isolates were negative by all 3 phenotypic methods used in our study. Cramton et al. (1999) suggested that this discrepancy may arise from point mutations in the $i c a$ locus or other yet unknown factor that negatively affects biofilm synthesis. Baselga et al. (1993) indicated that phenotypic expression of the biofilm synthesis was quite sensitive to in vitro conditions. Ciftci et al. (2009) mentioned possible role of genes in the ica locus involved in controlling slime expression. Nourbakhsh and Namvar (2016) investigated possible role of 12 genes involved in biofilm formation in MRSA and found that all strains had biofilm-producing ability with different degrees due to the different prevalence rates of these genes. Pereyra et al. (2016) emphasized that overexpression of $i c a D$ and $f n b B$ genes was necessary to reach the highest invasion rates, irrespective of genes related to adherence and biofilm formation. Another gene involved in biofilm formation and persistence of Staph. aureus on the mammary gland epithelium is bap (Cucarella et al., 2001), which was detected only in 15 (13.4\%) of the isolates in the current study. Our results are comparable to the study carried out by Zuniga et al. (2015), who reported that $15.8 \%$ of Staph. aureus strains obtained from bovine subclinical mastitis cases in Brazil harbored this gene. However, Salimena et al. (2016) in Brazil detected bap in $95.6 \%$ of the isolates, which is the highest prevalence rate reported to date, whereas some authors did not detect this gene among Staph. aureus from subclinical bovine mastitis cases (Sung et al., 2008; Vautor et al., 2008; Szweda et al., 2012; Xu et al., 2015). Khoramrooz et al. (2016) in Iran and Darwish and Asfour (2013) in Egypt detected this 
gene in 5 and $2.5 \%$ of their isolates, respectively. To our knowledge, this is the first time bap has been shown among Staph. aureus isolates of bovine mastitis origin in Turkey.

In the current study, all penicillin-resistant isolates (45.5\%) were also positive for blaZ. Similarly, da Costa Krewer et al. (2015) also reported higher rate (97.6\%) of blaZ among penicillin-resistant Staph. aureus from bovine mastitis in the northeast of Brazil. Another mechanism is methicillin resistance; MRSA has gained increasing importance in veterinary medicine in the last 2 decades, as MRSA show resistance not only $\beta$-lactams but also other classes of antimicrobials (Lee, 2003; Baptiste et al., 2005). In the current study, all oxacillin-resistant isolates were also positive for mecA (3.6\%). In a previous study, Ciftci et al. (2009) detected presence of mecA in only 4 of 59 (6.7\%) Staph. aureus isolates from bovine mastitis in Turkey.

Staphylococcal adhesins have been shown to be crucial for binding host surface. Thus, adhesins contribute to tissue adhesion and colonization in various infections, which is considered a critical stage in the initiation of infection (Klein et al., 2012; McCormack et al., 2014; Zuniga et al., 2015). However, little is known about surface adhesins of Staph. aureus strains isolated from bovine mastitis cases in Turkey. Our study marks the first time presence of some important adhesin genes ( cna, fnbA, and clfA) were investigated in Staph. aureus from bovine mastitis in Turkey.

The cna gene was detected in $87.5 \%$ of the isolates in the present study, which is very high percentage compared with previous studies. Zuniga et al. (2015) and Ikawaty et al. (2010) reported this gene in 47.4 and $49 \%$ of their isolates, respectively. A lower percentage of the cna gene was also identified in 10.7, 22.4, 22.5 , and $31.9 \%$ of Staph. aureus isolates subclinical bovine mastitis by Xu et al. (2015), Klein et al. (2012), Khoramrooz et al. (2016), and Ote et al. (2011), respectively.

The gene encoding the fibronectin-binding protein A $(f n b A)$ was detected in $77.7 \%$ of Staph. aureus isolates, which is nearly similar to findings of Khoramrooz et al. (2016), Xu et al. (2015), Ote et al. (2011), and Zuniga et al. (2015), who detected this gene in 72.5, 70, 83.8 , and $84.2 \%$ of the isolates, respectively. However, Ikawaty et al. (2010) and Kumar et al. (2011) reported higher prevalence rates of 96 and $100 \%$ of the Staph. aureus isolates, respectively. Also, a lower prevalence rate $(50.6 \%)$ was also reported by Klein et al. (2012).

Another important adhesin belong to MSCRAMM is clfA. This adhesin promotes virulence in invasive infections using different mechanisms, such as coating the bacterium with plasma fibrinogen and splitting of the complement opsonin C3b (McCormack et al., 2014). In our study, clfA was detected in $70 \%$ of Staph. aureus isolates, which is high compared with previous studies carried out by Klein et al. (2012; 50.6\%) and Ikawaty et al. (2010; 21\%). In contrast, Xu et al. (2015), Ote et al. (2011), and Pereyra et al. (2016) reported higher prevalence rate in their studies $(89.3,96.9$, and $100 \%$, respectively).

In conclusion, our study showed that Staph. aureus isolates of bovine subclinical mastitis carried widely both biofilm and adhesin genes involved in the pathogenesis of Staph. aureus infections, which indicate potential virulence of the isolates. In addition, high resistance was observed against $\beta$-lactams as well as moderate resistance against tetracycline and erythromycin, which are widely used in veterinary practice. Therefore, to achieve effective treatment of bovine mastitis cases and to prevent emergence of antibiotic-resistant bacteria, particular attention should be given to isolation of causative agent and determination of antimicrobial susceptibility.

\section{ACKNOWLEDGMENTS}

The authors thank Mustafa Kemal University Research Fund (Project Number: 08 L 0602) for financially supporting this study.

\section{REFERENCES}

Arciola, C. R., L. Baldassarri, and L. Montanaro. 2001. Presence of $i c a \mathrm{~A}$ and $i c a \mathrm{D}$ genes and slime production in a collection of staphylococcal strains from catheter-associated infections. J. Clin. Microbiol. 39:2151-2156.

Arciola, C. R., D. Campoccia, S. Gamberini, L. Baldassarri, and L. Montanaro. 2005. Prevalence of $c n a, f n b A$ and $f n b B$ adhesin genes among $S$. aureus isolates from orthopaedic infections associated to different types of implant. FEMS Microbiol. Lett. 246:81-86.

Baptiste, K. E., K. Williams, J. Williams, A. Wattret, P. D. Clegg, S. Dawson, J. E. Corkill, T. O'Neill, and C. A. Hart. 2005. Methicillin resistant staphylococci in companion animals. Emerg. Infect. Dis. 11:1942-1944.

Baselga, R., I. Albizu, M. De La Cruz, E. Del Cacho, M. Barberan, and B. Amorena. 1993. Phase variation of slime production in Staphylococcus aureus: Implications in colonization and virulence. Infect. Immun. 61:4857-4862.

Beco, L., E. Guaguère, C. Lorente Méndez, C. Noli, T. Nuttall, and M. Vroom. 2013. Suggested guidelines for using systemic antimicrobials in bacterial skin infections: part 2-antimicrobial choice, treatment regimens and compliance. Vet. Rec. 172:156-160.

Choi, S. M., S. Kim, H. Kim, D. G. Lee, J. H. Choi, J. H. Yoo, J. H. Kang, W. S. Shin, and M. W. Kang. 2003. Multiplex PCR for the detection of genes encoding aminoglycoside modifying enzymes and methicillin resistance among Staphylococcus species. J. Korean Med. Sci. 18:631-636.

Christensen, G. D., W. A. Simpson, J. J. Younger, L. M. Baddour, F. F. Barrett, D. M. Melton, and E. H. Beachey. 1985. Adherence of coagulase-negative staphylococci to plastic tissue culture plates: a quantitative model for the adherence of staphylococci to medical devices. J. Clin. Microbiol. 22:996-1006. 
Ciftci, A., A. Findik, E. E. Onuk, and S. Savasan. 2009. Detection of methicillin resistance and slime factor production of Staphylococcus aureus in bovine mastitis. Braz. J. Microbiol. 40:254-261.

Clinical and Laboratory Standards Institute. 2008. Performance standards for antimicrobial disk and dilution susceptibility tests for bacteria isolated from animals; Approved Standard. 3rd ed. CLSI document M31-A3. CLSI, Wayne, PA.

Cramton, S. E., C. Gerke, N. F. Schnell, W. W. Nichols, and F. Gotz. 1999. The intercellular adhesion (ica) locus is present in Staphylococcus aureus and is required for biofilm formation. Infect. Immun. 67:5427-5433.

Cucarella, C., M. Angeles-Tormo, C. Ubeda, M. Pilar-Trotonda, M. Monzon, C. Peris, B. Amorena, I. Lasa, and J. S. Penades. 2004 Role of biofilm associated protein Bap in the pathogenesis of bovine Staphylococcus aureus. Infect. Immun. 72:2177-2185.

Cucarella, C., C. Solano, J. Valle, B. Amorena, I. Lasa, and J. R. Penades. 2001. Bap a, Staphylococcus aureus surface protein involved in biofilm formation. J. Bacteriol. 183:2888-2896.

da Costa Krewer, C., E. S. Amanso, G. V. Gouveia, R. L. Souza, M. M. Costa, and R. A. Mota. 2015. Resistance to antimicrobials and biofilm formation in Staphylococcus spp. isolated from bovine mastitis in the Northeast of Brazil. Trop. Anim. Health Prod. 47:511-518.

Darwish, S. F., and H. A. Asfour. 2013. Investigation of biofilm forming ability in staphylococci causing bovine mastitis using phenotypic and genotypic assays. ScientificWorldJournal 2013:378492-378500.

Dhanawade, N. B., D. R. Kalorey, R. Srinivasan, S. B. Barbuddhe, and N. V. Kurkure. 2010. Detection of intercellular adhesion genes and biofilm production in Staphylococcus aureus isolated from bovine subclinical mastitis. Vet. Res. Commun. 34:81-89.

Freeman, D. J., F. R. Falkiner, and C. T. Keane. 1989. New method for detecting slime production by coagulase negative staphylococci. J. Clin. Pathol. 42:872-874.

Gerke, C., A. Kraft, R. Sussmuth, O. Schweitzer, and F. Gotz. 1998. Characterization of the $\mathrm{N}$-acetylglucosaminyltransferase activity involved in the biosynthesis of the Staphylococcus epidermidis polysaccharide intercellular adhesin. J. Biol. Chem. 273:18586-18593.

Gulcu, H. B., and H. B. Ertas. 2004. Elazığ yöresinde mezbahada kesilen ineklerde mastitisli meme loblarmmn bakteriyolojik incelenmesi. Turk. J. Vet. Anim. Sci. 28:91-94.

Güler, L., Ü. Ok, K. Gündüz, Y. Gülcü, and H. H. Hadimli. 2005. Antimicrobial susceptibility and coagulase gene typing of Staphylococcus aureus isolated from bovine clinical mastitis cases in Turkey. J. Dairy Sci. 88:3149-3154.

Haveri, M., M. Hovinen, A. Roslöf, and S. Pyörälä. 2008. Molecular types and genetic profiles of Staphylococcus aureus strains isolated from bovine intramammary infections and extramammary sites. J. Clin. Microbiol. 46:3728-3735.

Ikawaty, R., E. C. Brouwer, E. Van Duijkeren, D. Mevius, J. Verhoef, and A. C. Fluit. 2010. Virulence factors of genotyped bovine mastitis Staphylococcus aureus isolates in the Netherlands. Int. J. Dairy Sci. 5:60-70.

Ikiz, S., B. Başaran, E. B. Bingöl, Ö. Çetin, G. Kaşıkçı, N. Y. Özgür, M. Uçmak, Ö. Yılmaz, and M. C. Gündüz. 2013. Ssabuncu. Presence and antibiotic susceptibility patterns of contagious mastitis agents (Staphylococcus aureus and Streptococcus agalactiae) isolated from milks of dairy cows with subclinical mastitis. Turk. J. Vet. Anim. Sci. 37:569-574.

Jensen, L. B., N. Frimodt-Møller, and F. M. Aarestrup. 1999. Presence of erm gene classes in 271 gram-positive bacteria of animal and human origin in Denmark. FEMS Microbiol. Lett. 170:151-158.

Khoramrooz, S. S., F. Mansouri, M. Marashifard, S. A. Malek Hosseini, F. Akbarian Chenarestane-Olia, B. Ganavehei, F. Gharibpour, A. Shahbazi, M. Mirzaii, and D. Darban-Sarokhalil. 2016. Detection of biofilm related genes, classical enterotoxin genes and agr typing among Staphylococcus aureus isolated from bovine with subclinical mastitis in southwest of Iran. Microb. Pathog. 97:45-51.

Klein, R. C., M. H. Fabres-Klein, M. A. Brito, L. G. Fietto, and O Ribon Ade. 2012. Staphylococcus aureus of bovine origin: Genetic diversity, prevalence and the expression of adhesin-encoding genes. Vet. Microbiol. 160:183-188.
Kumar, R., B. R. Yadav, S. K. Anand, and R. S. Singh. 2011. Prevalence of adhesin and toxin genes among isolates of Staphylococcus aureus obtained from mastitis cattle. World J. Microbiol. Biotechnol. 27:513-521.

Kumar, R., B. R. Yadav, and R. S. Singh. 2010. Genetic determinants of antibiotic resistance in Staphylococcus aureus isolates from milk of mastitic crossbred cattle. Curr. Microbiol. 60:379-386.

Lee, J. H. 2003. Methicillin (oxacillin)-resistant Staphylococcus aureus strains isolates from major food animals and their potential transmission to humans. Appl. Environ. Microbiol. 69:6489-6494.

Macun, H. C. I. P. Yagcı, N. Unal, H. Kalender, F. Sakarya, and M. Ylldırım. 2011. Agent isolation and antibiotic resistance in dairy cows with subclinical mastitis in Kırıkkale. Journal of Faculty of Veterinary Medicine, Erciyes University 8:83-89. [In Turkish.]

McCormack, N., T. J. Foster, and J. A. Geoghegan. 2014. A short sequence within subdomain N1 of region A of the Staphylococcus aureus MSCRAMM clumping factor $\mathrm{A}$ is required for export and surface display. Microbiology 160:659-670.

Nourbakhsh, F., and A. E. Namvar. 2016. Detection of genes involved in biofilm formation in Staphylococcus aureus isolates. GMS Hyg. Infect. Control 11:Doc07.

Oliver, S. P., and S. E. Murinda. 2012. Antimicrobial resistance of mastitis pathogens. Vet. Clin. North Am. Food Anim. Pract. 28:165185.

Olsen, J. E., H. Christensen, and F. M. Aarestrup. 2006. Diversity and evolution of blaZ from Staphylococcus aureus and coagulasenegative staphylococci. J. Antimicrob. Chemother. 57:450-460.

Ote, I., B. Taminiau, J. N. Duprez, I. Dizier, and J. G. Mainil. 2011 Genotypic characterization by polymerase chain reaction of Staphylococcus aureus isolates associated with bovine mastitis. Vet. Microbiol. 153:285-292.

Patti, J. M., B. L. Allen, M. J. McGavin, and M. Höök. 1994. MSCRAMM-mediated adherence of microorganisms to host tissues. Annu. Rev. Microbiol. 48:585-617.

Pereyra, E. A., F. Picech, M. S. Renna, C. Baravalle, C. S. Andreotti, R. Russi, L. F. Calvinho, C. Diez, and B. E. Dallard. 2016. Detection of Staphylococcus aureus adhesion and biofilm-producing genes and their expression during internalization in bovine mammary epithelial cells. Vet. Microbiol. 183:69-77.

Quinn, P. J., M. E. Carter, B. K. Markey, and G. R. Carter. 1998 Clinical Veterinary Microbiology. 2nd ed. Mosby, London, UK.

Salimena, A. P., C. C. Lange, C. Camussone, M. Signorini, L. F. Calvinho, M. A. Brito, C. A. Borges, A. S. Guimarães, J. B. Ribeiro, L. C. Mendonça, and R. H. Piccoli. 2016. Genotypic and phenotypic detection of capsular polysaccharide and biofilm formation in Staphylococcus aureus isolated from bovine milk collected from Brazilian dairy farms. Vet. Res. Commun. http://dx.doi. org/10.1007/s11259-016-9658-5.

Sawant, A. A., B. E. Gillespie, and S. P. Oliver. 2009. Antimicrobial susceptibility of coagulase-negative Staphylococcus species isolated from bovine milk. Vet. Microbiol. 134:73-81.

Strommenger, B., C. Kettlitz, G. Werner, and W. Witte. 2003. Multiplex PCR assay for simultaneous detection of nine clinically relevant antibiotic resistance genes in Staphylococcus aureus. J. Clin. Microbiol. 41:4089-4094.

Sung, J. M., D. H. Lloyd, and J. A. Lindsay. 2008. Staphylococcus aureus host specificity: comparative genomics of human versus animal isolates by multi-strain microarray. Microbiology 154:1949-1959.

Szweda, P., M. Schielmann, S. Milewski, A. Frankowska, and A. Jakubczak. 2012. Biofilm production and presence of $i c a$ and bap genes in Staphylococcus aureus strains isolated from cows with mastitis in the eastern Poland. Pol. J. Microbiol. 61:65-69.

Taponen, S., and S. Pyörälä. 2009. Coagulase-negative staphylococci as cause of bovine mastitis - Not so different from Staphylococcus aureus. Vet. Microbiol. 134:29-36.

Tel, O. Y., M. Bayraktar, and O. Keskin. 2012. Investigation of antibiotic resistance among Staphylococcus aureus strains of human and bovine origin. Ankara Univ. Vet. Fak. Derg. 59:191-196.

Turkyilmaz, S., and S. Eskiizmirliler. 2006. Detection of slime factor production and antibiotic resistance in Staphylococcus strains 
isolated from various animal clinical samples. Turk. J. Vet. Anim. Sci. 30:201-206.

Turutoğlu, H., S. Ercelik, and D. Ozturk. 2006. Antibiotic resistance of Staphylococcus aureus and coagulase-negatıve staphylococci isolated from bovine mastitis. Bulletin of the Veterinary Institute in Pulawy 50:41-45.

Ünal, N., and E. İstanbulluoğlu. 2009. Phenotypic and genotypic features of Staphylococcus aureus strains isolated from cattle and humans. Veterinary Journal of Ankara University 56:119-126.

Vancraeynest, D., K. Hermans, and F. Haesebrouck. 2004. Genotypic and phenotypic screening of high and low virulence Staphylococcus aureus isolates from rabbits for biofilm formation and MSCRAMMs. Vet. Microbiol. 103:241-247.

Vasudevan, P., M. K. Nair, T. Annamalai, and K. S. Venkitanarayanan. 2003. Phenotypic and genotypic characterization of bovine mastitis isolates of Staphylococcus aureus for biofilm formation. Vet. Microbiol. 92:179-185.

Vautor, E., G. Abadie, A. Pont, and R. Thiery. 2008. Evaluation of the presence of the bap gene in Staphylococcus aureus isolates recovered from human and animals species. Vet. Microbiol. 127:407-411.
Vesterholm-Nielsen, M., M. Olhom Larsen, J. Elmerdahl Olsen, and F. Moller Aarestrup. 1999. Occurrence of the blaZ gene in penicillin resistant Staphylococcus aureus isolated from bovine mastitis in Denmark. Acta Vet. Scand. 40:279-286.

Xu, J., X. Tan, X. Zhang, X. Xia, and H. Sun. 2015. The diversities of staphylococcal species, virulence and antibiotic resistance genes in the subclinical mastitismilk from a single Chinese cow herd. Microb. Pathog. 88:29-38.

Yesilmen, S., N. Ozyurtlu, and S. Bademkıran. 2012. The isolation of subclinical mastitis agents and determination of the sensitive antibiotics in dairy cows in Diyarbakır province. Dicle Univ. J. Vet. Fac. Vet. Med. 1:24-29.

Zuniga, E., P. A. Melville, A. B. Saidenberg, M. A. Laes, F. F. Gonsales, S. R. Salaberry, F. Gregori, P. E. Brandão, F. G. Dos Santos, N. E. Lincopan, and N. R. Benites. 2015. Occurrence of genes coding for MSCRAMM and biofilm-associated protein Bap in Staphylococcus spp. isolated from bovine subclinical mastitis and relationship with somatic cell counts. Microb. Pathog. 89:1-6. 